Bull. Fac.Agric., Cairo Univ., 65:370-385 (2014).

\title{
ATTAINING ONE MONTH -LATE- PLANTING OF BARBADENSE COTTONS GROWN IN THE RIVER NILE DELTA
}

(Received:8.12.2014)

\author{
By \\ A. M.A. Abdalla, S. E. D. Elayan , N. S. D Abdel-Gawad* and W. A. El- Faramawy* \\ Agronomy Department, Faculty of Agriciculture, Cairo University, Giza,Egypt \\ *Cotton Research Institute, Agricultural Research Center, Giza, Egypt
}

\begin{abstract}
Egyptian cotton growers are facing an unavoidable problem of late planting of cotton. To address such problem, four barbadense genotypes; two long staple [cultivar G86 and promising line of the cross (10229 x Giza 86)] and two extra long staple [cultivar G88 and promising line of the cross (Giza 84x G70xG51BxPima62)] were grown in three planting dates (April 15, April 30 and May15) at Nile Delta cotton zone, Egypt, during two successive seasons 2012 and 2013. Research objectives were to determine planting date effects on the performance of selected genotypes, data variability, and relation with air thermal units. The results showed that the PDs and genotypes had less effect on the data normality in both seasons with few exceptions. Slightly negative to positive skewness and kurtosis were observed. Moderate to high variability (CV \%) was observed in yield determinants; while moderate to low variability existed in fiber and yarn determinants. Planting date (PD) and genotype $(\mathrm{G})$ influenced significantly $(\mathrm{P}<0.01)$ yield, fiber and yarn variables. However, the PD x G interaction was not significant for most lint and yarn traits. With the exception of plant height and yarn evenness, mean performance of yield and fiber determinants of genotypes declined by delaying planting date. The delayed planting from 30 April to 15 May had more adverse effect on most traits than the delayed planting from 15 to 30 April. For example, seed cotton yield per plant lost 6.38 and $9.15 \mathrm{gm}$ in the first season compared with 8.14 and $8.47 \mathrm{gm}$ in the second season due to the first and second 15-day delay of planting, respectively. Except for yarn traits, response curves showed linearly negative effects of delaying planting on cotton yield and fiber traits in the two seasons. The two promising crosses were significantly better than their corresponding cultivars especially in yield and its attributes. Averaged over the two seasons, heat units efficiency use (HUE) measured as a number of open bolls/plant corresponded to each accumulated heat unit (AHU) were 106.14, 129.15 and $164.41 \mathrm{hu} / \mathrm{boll}$ for the first, second and third planting dates, respectively. Discussion on yield and its attributes, fiber and yarn properties pointed out that the two promising crosses possessed potential to tolerate conditions of late planting, suggesting their use to replace the present cultivars and utilize in breeding program aimed at developing barbadense genotypes to grow under late planting of agroclimatic conditions of the River Nile Delta.
\end{abstract}

Key words: barbadense, Cotton, fiber quality, genotypes, sowing dates, yield.

\section{INTRODUCTION}

Cotton (Gossypium spp.) is a widespread tropical and subtropical plant recognized for its natural fibers, vegetable oil and animal cake. Cotton is a perennial plant turned, for agronomical purposes, to grow annually. The plant grows in temperatures ranged from 20/12 to $40 / 32^{\circ} \mathrm{C}$ (day/night) in well watered and fertilized conditions (Burke and Wanjura, 2010). Egyptian cottons (Gossypium barbadense L.) genotypes spun into yarn in high counts and use to make the most fine comfort textile and clothes. For Egyptians cotton was considered their white gold. The verb "was" here imply that gradual changes in production practices along with changes in growing environments 
proceeded not only to reduce the area projected to cotton farming, but also brought forward threats for the Egyptian cotton cultivation and breeding. These shrinking variables, and some more connected to economic-political issues led to reducing the cultivated area during the season of 2010 and 2011 to as low as 375 thousands feddan (feddan $=4200 \mathrm{~m}^{2}$ ), while the cultivated area reached as high as a million and half feddan in the seasons from 1968 to 1970 (Egyptian Cotton Gazette, 2012). Justifying such reduction is important for maintaining cotton cultivation in the small area of landholders distinguishing Egyptian cultivation around the River Nile.

On the other hand, the level of success in selecting genotypes tolerant to late planting critically depends upon two factors. First, the accuracy of field experimentation and estimation of the mean performance that can be quantified through investigating the effects of treatments on data variability. Second, the genotype potential under late sowing that can be measured through investigating the magnitude of genotype $\mathrm{x}$ planting date interaction. Different cultivars have their own genetic potential and they respond differently to various biotic and abiotic stresses as well as climatic conditions (Bange and Milroy, 2004). Cotton boll maturity (fiber maturity)is particularly sensitive to environment, genotype and thermal air temperature (Bradow and Bauer, 1998). Cotton sowing date is one of the most important management factors influencing the high yield and prized quality of indeterminate-full-season ecotypes of Egyptian barbadense. Adverse conditions of late sowing could mask any genetic improvement in yield and fiber (Pettigrew and Meredith, 2009). The long duration winter crops that overlapped with cotton cultivations were not encouraged for sowing before cotton. Cotton growers, however, preferred to grow the liquid money winter crops like the Egyptian clover, wheat, or faba bean in account to summer cotton cultivations. Moreover, Egyptian genotypes bred for decades to grow in full-season hence to sow, in the Delta Nile cotton zone, at most, by the first week of April to get their potential. For the genotypes bred and grown under full-season conditions, late sowing is considered as a stress condition (Abdalla, 2013). Choosing genotype and planting time for late planting, however, is not an easy task. This decision must fulfill a balance between sowing too late and enduring problems associated with loosing potential yield due to the Egyptian hot summer. Therefore, the current study was not initiated to determine the optimal planting date (PD) of barbadense cottons; it was initiate only to insure the possibility to alter planting date of the Egyptian barbadense ecotypes to be mid April or later instead of early April. Agronomists have also developed new cultivation practices (Abo El-Zahab, 1994) to help tolerate late planting stress and accelerate the crop cycle, while reducing the vegetative vigor. Proper PD helps to establish a good stand, start flowering and boll set well earlier as compared to late ones (Boquet and Clawson, 2009) and as a consequence attaining yield potential under particular agro-climatic conditions. Abdalla (2013) studied the integrity of ANOVA and other statistical models for interpreting the genotype $\mathrm{x}$ planting date interaction associated with regular and severe late planting date. The study used a population of 22 barbadense genotypes representing obsolete, exotic, cultivated, and experimental strains grown in six PD environments. The study included the two experimental crosses employed herein and they were among the promising genotypes selected for potential tolerance to late planting. Thus, it is important to compare these, about to release as cultivars, promising crosses with other cultivated genotypes in their real grown area for late and very late planting date.

The main objective of the present research was to investigate the response of cotton genotypes to a range of planting dates through its effects on cotton yield, fiber and yarn quality variables. Effects of temperature fluctuation on yield and quality traits of different cotton genotypes were targeted too.

\section{MATERIALS AND METHODS 2.1. Experimental site and agro-metrological conditions}

The current investigation planned to compare the performance of newly released strains and promising crosses of barbadense cottons with their long and extra long staple genotypes in their real growing environments under regular 
and late planting conditions. Field experiments were conducted during 2012 and 2013 seasons at the Agricultural research station, Sakha, Kafr Elsheikh, Egypt. The experimental station is located in the Egyptian Delta River Nile cotton zone, [(Latitude 31.07, Longitude 30.57, Elevation $20 \mathrm{~m}$. annual mean temperature $19.5^{\circ} \mathrm{C}$, relative humidity $65 \%$, wind speed 117.2 $\mathrm{Km} /$ day and potential sunshine hours PSH 9.3hr]. Monthly mean weather conditions (air temperature $\left(\mathrm{Temp} .{ }^{0} \mathrm{C}\right)$, rainfall $(\mathrm{mm})$, relative humidity ( $\mathrm{RH} \%$ ) and soil temperature) during crop growth seasons (April-Oct) for Sakha Weather Station are presented in Table (1).

Soil samples for the two seasons were analyzed by the facilities of Soils, Water and Environment institute (SWEI) at Giza. The soil
$31 \mathrm{~mm}$ to $34 \mathrm{~mm}$ (Anonymous, 2012). The other two genotypes Giza 88 (cultivated) and the experimental promising cross $(\mathrm{G} 84 \mathrm{xG} 70 \mathrm{x}$ G51Bx Pima62), are from extra long staple stocks with fiber length range of $35-39 \mathrm{~mm}$.

\subsection{Culture practices}

After germination, the thinning operation was completed; normal plant-to-plant spacing $(25 \mathrm{~cm})$ was maintained. All cultural practices were done as recommended for the region. Nitrogen (60 kg N/fed.) as ammonium nitrate $(33.5 \% \mathrm{~N})$ and potassium $\left(48 \mathrm{~kg} \mathrm{~K}_{2} \mathrm{O} /\right.$ fed.) as potassium sulphate $\left(48 \% \mathrm{~K}_{2} \mathrm{O}\right)$ were partly side dressed at the first and second irrigations. Phosphorus $\left(\begin{array}{lll}30 & \mathrm{~kg} & \mathrm{P}_{2} \mathrm{O}_{5}\end{array}\right)$ as ordinary superphosphate $\left(15.5 \% \mathrm{P}_{2} \mathrm{O}_{5}\right)$ was broadcasted at planting.

Table (1): Monthly mean weather conditions during crop growth season (April-Oct)

\begin{tabular}{|c|c|c|c|c|c|c|c|c|c|c|}
\hline \multirow[b]{3}{*}{ Month } & \multicolumn{5}{|c|}{2012} & \multicolumn{5}{|c|}{2013} \\
\hline & \multicolumn{2}{|c|}{ Temp. ${ }^{0} \mathrm{C}$} & \multirow[t]{2}{*}{ RH\% } & \multirow{2}{*}{\begin{tabular}{|c|} 
Rainfall \\
$(\mathbf{m m})$
\end{tabular}} & \multirow[t]{2}{*}{ Soil Temp. } & \multicolumn{2}{|c|}{ Temp. ${ }^{0} \mathrm{C}$} & \multirow[t]{2}{*}{ RH\% } & \multirow{2}{*}{$\begin{array}{c}\text { Rainfall } \\
\text { (mm) }\end{array}$} & \multirow[t]{2}{*}{ Soil Temp. } \\
\hline & Min & Max & & & & Min & Max & & & \\
\hline April & 13.80 & 26.70 & 63.90 & 2.30 & 24.00 & 12.92 & 25.62 & 68.47 & 0.82 & 25.00 \\
\hline May & 13.50 & 25.10 & 70.40 & 1.70 & 23.00 & 18.15 & 31.08 & 69.28 & 0.09 & 27.00 \\
\hline June & 15.40 & 27.20 & \begin{tabular}{|c|}
69.40 \\
\end{tabular} & 1.80 & 25.20 & 20.57 & 31.06 & 71.26 & 0.02 & \begin{tabular}{|l|}
29.30 \\
\end{tabular} \\
\hline Jul. & 21.80 & 32.70 & 74.20 & 0.80 & 31.10 & 22.13 & 33.18 & 73.98 & 0.11 & 31.60 \\
\hline Aug. & 22.70 & 34.00 & 73.70 & 0.10 & 31.10 & 22.29 & 33.25 & \begin{tabular}{|l|}
73.84 \\
\end{tabular} & 0.04 & 31.30 \\
\hline Sept. & 20.60 & 31.80 & 70.90 & 0.00 & 27.80 & 20.53 & 31.99 & 71.78 & 0.02 & 28.80 \\
\hline Oct. & 19.00 & 29.60 & 74.40 & 0.20 & 27.40 & 18.13 & 28.79 & 69.74 & 0.10 & 30.20 \\
\hline
\end{tabular}

texture was clay loam in both seasons; soil ingredients averaged across seasons were clay $(38 \%)$, silt $(35 \%)$ and sand $(30 \%)$. The average percentage of organic matter was 1.63 with soil $\mathrm{PH}$ of 8.3 averaged across the two seasons. Electric conductivity (EC) was 3.5 and $4.2 \mathrm{dSm}^{-1}$ for the first and second year, respectively. There were no problems of major elements; potassium (K) at soil depth of $0-16 \mathrm{~cm}$ was $154 \mathrm{ppm}$ per each $\mathrm{kg}$ soil.

\subsection{Experimental materials}

Two year field experimentation were maintained by Cotton Regional Evaluation Division, Cotton Research Institute, Ministry of Agriculture, Egypt, during the two successive seasons of 2012 and 2013. Sowing dates were separated using 15-day intervals with initial planting on April 15. The studied genotypes were four. Two genotypes; Giza 86 (cultivated) and its experimental promising cross $10229 \mathrm{x}$ Giza 86 are belonging to the Delta long staple length stocks, their fiber length range from

\subsection{Recorded Data}

At harvest, ten plants were randomly taken from the inner ridges of each sub-plot. The measured parameters included plant height ( $\mathrm{PH}$ $\mathrm{cm}$ ), days to first flower (DFF), days to first boll (DFB), number of bolls/plant (NB/P), and boll weight (BW gm); calculated by dividing seed cotton yield per plant by the number of open bolls per plant. Seed cotton yield per plant (gm), seed cotton yield per feddan (kentar) were determined by picking all open bolls of the three inner ridges in kilogram and then converted to kentar/feddan. One kentar of seed cotton $(\mathrm{SC})=$ $157.5 \mathrm{~kg}$, one kentar of lint cotton (LC) $=50 \mathrm{~kg}$ and one Feddan $=4200 \mathrm{~m}^{2}$. Lint yields per plant and per feddan were estimated by multiplying the seed cotton by the lint percentage, lint percent, age (LC/SC) 100. Seed index, is the weight of 100 seeds in grams. A sample of 30 gm of lint was taken randomly from each subplot for recording fiber quality determinants. Cotton fibers were conditioned for 24 hours 
under control of $20 \pm 2^{\circ} \mathrm{C}$ and relative humidity $65 \pm 2 \%$. HVI instrument system was used to determine fiber properties according to (ASTM: 4604-05 (2005). Cotton fiber characteristics included the upper half mean length UHML $(\mathrm{mm})$, uniformity index (UI \%), micronaire value (Mic), fiber strength; FS (g/tex), fiber elongation percentage color reflectance (whiteness) percent (Rd \%) and yellowness degree (+b). Yarn properties and testing were done with replicated samples under standard opening, carding and spinning conditions (count $60 \mathrm{~s}$, and 4.2 twist multiplier). Lea count strength product (LCSP) was measured by good brand lea tester according to ASTM D1578-93R00 (2005), yarn strength (cN/tex) and elongation (\%) were measured by Statimat ME automatic tensile, yarn evenness. The yarn imperfections of thin, thick places and neps were measured by Uster (1998).

\subsection{Statistical analyses}

The collected data were subjected to a twostage data analysis. First, the data set were subjected to descriptive statistics analysis including central location, variation, and population shape parameters. Goodness-of-fit was tested using Anderson -Darling test, calculating test statistic $\left(A^{2}\right)$ that compared with an appropriate critical value (Anderson and Darling, 1954). Second, the treatments of each season were distributed in a split plot arrangement of randomized complete blocks design, keeping the three adjacent sowing dates as main plots and the four genotypes as subplots. The experiment was conducted in three replications with sub plot size of $18 \mathrm{~m}^{2}$ including 6 rows $(5 \mathrm{~m}$ long, $25 \mathrm{~cm}$ distance between a two-vigor plant hills and $60 \mathrm{~cm}$ between rows). Combined analyses of variance and regression analysis of both seasons were carried out, but first homogeneity of error variances were tested according to Snedecor and Cochran (1983). The least significant difference (LSD) test at suitable probability level was used to determine the significance of statistical differences between treatment means. The heat units of growing degree-days (GDD) for each PD were calculated by the equation

$$
\mathrm{GDD}=\left\{\sum_{\mathrm{t}_{1}}^{\mathrm{t}_{2}}\left(\frac{\mathrm{T}_{\text {Max }}-\mathrm{T}_{\min }}{2}\right)\right\}-\mathrm{T}_{\text {base }}, \text { where }
$$

$\mathrm{T}_{\max }$ and $\mathrm{T}_{\min }$ are maximum and minimum daily air temperatures, respectively, $\mathrm{T}_{\text {base }}$ is the base temperature (below which no development occurs) and $t_{1}$ and $t_{2}$ are time intervals (Baskerville and Emin, 1969). Base temperature for cotton development is $12.8^{\circ} \mathrm{C}$ (Young et al. 1980). The heat units efficiency use (hu/boll)= (Total heat units across growing season)/ (No. of open bolls per plant). Authentic versions software of EXCEL, MINITAB, and IRRESTAT statistical packages were used upon needed.

\section{RESULTS AND DISCUSSION \\ 3.1. Data variability and goodness-of-fit}

Statistics is basically utilized to adapt, interpret and represent data. For justifying the amount of variability found in each trait, descriptive statistics of the two seasons were calculated and presented in Table (2). Except for $\mathrm{PH}$, the standard deviation showed relatively small values comparative to the associated mean, indicating that the mean performances of these treats were gathered around the grand mean value.

The standard deviation describes where any given data point is located with respect to the population mean. Thus, the minor differences in the standard deviation values between the two planting seasons (except for PH and DFB) may reflect the stability of seasonal variation. Coefficients of variation (CV \%) express the ratio of standard deviation over mean of a data set, so data sets with different means can be compared in terms of relative variability. Its most common use, however, is to measure the validity of field experiments (Bowman, 2001). The current study considered data sets with CV of less than $10 \%$ having "low variability". Sets with CV between $10 \%$ and $20 \%$ have "moderate variability". Data sets with CV greater than $20 \%$ have "high variability" (Snedecor and Cochran, 1983). Therefore, DFB and FL exhibited low variability. Moderate to high variability was associated with data sets of $\mathrm{PH}, \mathrm{NB} / \mathrm{P}$ and $\mathrm{SC} / \mathrm{F}$ plant height (Table 2). Similar cotton variability reported by Johnson et al. (2002). Asif et al. (2008) reported CV of 5.4\%, 6.13\%, and $4.5 \%$ for fiber length, Mic, and fiber strength, respectively. Skewness and kurtosis values describe the symmetry and vertex of the sampled 
distribution relative to the normal distribution. Fiber length at the two seasons and micronaire at the first one were positively skewed. Most of the remaining traits were slightly negatively skewed with the median greater than the mean, which indicated that these traits spread out more combined. First order interaction of PD x G was highly significant for $\mathrm{PH}$ at $\mathrm{S} 1$ and combined, while it was significant at S2, for DFF it was significant at $\mathrm{S} 2$ and highly significant in combined data, for DFB it was significant only with combined data, for NB/P it was significant

Table (2): Summary statistics of the overall data sets for some selected yield, fiber and yarn traits in the two growing seasons, 2012 and 2013

\begin{tabular}{|c|c|c|c|c|c|c|c|c|c|c|c|c|c|c|}
\hline Variable & \multicolumn{2}{|c|}{ PH (cm) } & \multicolumn{2}{|c|}{ DFB } & \multicolumn{2}{|c|}{ NB/P } & \multicolumn{2}{|c|}{$\operatorname{SCY}(k / f)$} & \multicolumn{2}{|c|}{ FL $(\mathrm{mm})$} & \multicolumn{2}{|c|}{ Mic. } & \multicolumn{2}{|c|}{ YE } \\
\hline Season & 2012 & 2013 & 2012 & 2013 & 2012 & 2013 & 2012 & 2013 & 2012 & 2013 & 2012 & 2013 & 2012 & 2013 \\
\hline Mean & 138.5 & 126.7 & 122.2 & 121.9 & 15.4 & 14.5 & 10.4 & 10.5 & 33.5 & 33.4 & 4.0 & 3.8 & 19.6 & 20.8 \\
\hline Median & 140.3 & 129.5 & 121.5 & 122.0 & 16.0 & 15.0 & 10.8 & 10.6 & 33.4 & 33.4 & 4.0 & 3.7 & 20.0 & 21.1 \\
\hline Tr. $M$ & 139.2 & 127.6 & 122.2 & 121.9 & 15.5 & 14.6 & 10.5 & 10.6 & 33.5 & 33.4 & 4.0 & 3.8 & 19.6 & 20.9 \\
\hline Min & 109.0 & 78.0 & 115.0 & 117.0 & 9.8 & 9.0 & 5.4 & 5.4 & 31.9 & 30.2 & 3.2 & 3.0 & 16.0 & 18.8 \\
\hline Max & 156.0 & 150.0 & 129.0 & 128.0 & 19.0 & 20.0 & 13.4 & 13.8 & 35.9 & 36.7 & 4.7 & 4.6 & 22.6 & 22.0 \\
\hline $\mathbf{Q}_{1}$ & 130.5 & 120.4 & 119.0 & 120.0 & 13.7 & 13.0 & 8.6 & 9.1 & 33.0 & 32.3 & 3.6 & 3.4 & 17.5 & 19.9 \\
\hline $\mathbf{Q}_{3}$ & 147.0 & 136.8 & 125.8 & 124.0 & 17.3 & 17.0 & 12.4 & 12.9 & 34.1 & 34.3 & 4.3 & 4.3 & 21.1 & 21.6 \\
\hline SK & -0.8 & -0.9 & 0.0 & 0.4 & -0.8 & -0.2 & -0.7 & -0.6 & 0.5 & 0.2 & -0.2 & 0.0 & -0.6 & -0.8 \\
\hline $\mathbf{K u}$ & 0.8 & 1.7 & -1.1 & -0.7 & -0.1 & -0.6 & -0.5 & -0.6 & 0.5 & 0.0 & -0.9 & -1.3 & -0.9 & -0.6 \\
\hline SD & 11.3 & 15.1 & 4.0 & 2.9 & 2.6 & 2.9 & 2.3 & 2.5 & 0.9 & 1.5 & 0.4 & 0.4 & 2.1 & 1.0 \\
\hline $\mathbf{C V}$ & 8.1 & 11.9 & 3.3 & 2.3 & 16.6 & 20.1 & 22.4 & 23.5 & 2.6 & 4.4 & 10.7 & 11.3 & 10.6 & 4.5 \\
\hline $\mathbf{N T}(\mathbf{P} *)$ & 0.30 & 0.41 & 0.36 & 0.20 & 0.11 & 0.50 & 0.10 & 0.10 & 0.51 & 0.66 & 0.35 & 0.10 & 0.06 & 0.04 \\
\hline
\end{tabular}

*Probability of normally according to Anderson-Darling test, Tr. M: trimmed mean, Min: minimum, Max: maximum value, $Q_{1}$ : first quartile, $\mathrm{Q}_{3}$ : third quartile, $\mathrm{SK}$ : skewness, Ku: kurtosis, SD: standard deviation and CV: coefficient of variation. PH: plant height. DFB: davs to first boll. NB/P: number of bolls per plant. SCY: seed cotton vield in kentar per feddan. Mic: micronaire

to the right of the mean yield. A negative degree of kurtosis was exhibited for most traits for $\mathrm{PH}$ in the two seasons. For testing the goodness-offit, the Anderson-Darling test was preferred because it is easy to adjust for moderate and small sample size, and it can be applied without prior information about the distribution type compared to the other "quantitative goodness-offit techniques" (D'Agostino and Stephens, 1986). Normality test showed that most traits were normally distributed ( $\operatorname{Pr}<0.01$ ) except for yarn elongation at season 2 (Table 2). Such normality can be clarified by the closeness of the three positional estimates as well as the low standard deviation values. Thus, the presented traits were normally distributed based on both symmetric and shape measurements (skewness and kurtosis) and the normality test.

\subsubsection{Yield and yield attributes}

Combined analysis of variance presented in Table (3) indicated that seasonal variations were highly significant for $\mathrm{PH}, \mathrm{NB} / \mathrm{P}, \mathrm{BW}$ and $\mathrm{LP} \%$, while it was significant for SC/P.

Planting dates (PD) across seasons and combined over seasons affected significantly all traits. Genotypic variation (G) was highly significant for all traits in both seasons and at S1only, for BW, L\% (except S2), SC/P, and $\mathrm{SC}(\mathrm{k} / \mathrm{f})$ it was highly significant. Excluding plant height, the greatest portion of the variation was exhibited by planting dates followed by genotypes and small portion, albeit, significant for the $P D \times G$ interaction (Table 3). For instance, $\mathrm{PD}$ of $\mathrm{NB} / \mathrm{P}$ in $\mathrm{S} 1$ contributed by $70 \%$ of the total variation, that was more than two fold of genotypes (26\%), the remained $4 \%$ allocated to $P D \times G$ interaction. Combined analysis of $S \times P D, S \times G$ as well as $S \times P D \times G$ were not significant in most traits indicated that planting date and genotypes, were not affected severely by seasonal variations. The subsequent results and discussion are built upon the mean performance of the individual season for the two studied factors and their interaction.

\subsubsection{Plant height}

The mean performance of yield and its attributes presented in Table (4) indicated that planting dates and genotypes had significant effects on plant height in both seasons. The latest planting date (May 15) gave the tallest plants $(145.83$ and $134.75 \mathrm{~cm})$ in both seasons, respectively. The shortest plants (133.50 and $120.00 \mathrm{~cm}$ ) were obtained from the earliest date (April 15) in both seasons, respectively. The 
Table(3): Analysis of variance for cotton yield and yield components in a cotton planting date and genotype study grown for two seasons; 2012(S1) and 2013(S2) and the combined ANOVA

\begin{tabular}{|c|c|c|c|c|c|c|c|c|c|c|c|c|c|}
\hline \multirow[b]{2}{*}{ SOV } & \multirow[b]{2}{*}{$d f$} & \multicolumn{3}{|c|}{ PH (cm) } & \multicolumn{3}{|c|}{ DFF (day) } & \multicolumn{3}{|c|}{ DFB (day) } & \multicolumn{3}{|c|}{ NB/P (No) } \\
\hline & & S1 & S2 & Comb. & S1 & S2 & Comb. & S1 & S2 & Comb. & S1 & S2 & Comb. \\
\hline $\mathbf{S}$ & 1 & & & $2713.39 * *$ & & & 11.68 & & & 1.125 & & & $13.96 * *$ \\
\hline $\mathbf{R}(\mathbf{S})$ & 4 & & & 3.09 & & & 2.63 & & & 1.98 & & & 1.11 \\
\hline PD & 2 & 458.11** & \begin{tabular}{|l}
$654.25 * *$ \\
\end{tabular} & $1103.60 * *$ & \begin{tabular}{|l}
$111.58 * * *$ \\
\end{tabular} & 98.11** & \begin{tabular}{|l}
$209.26 * *$ \\
\end{tabular} & \begin{tabular}{|l|}
230.0 *** \\
\end{tabular} & $90.53 * *$ & 303.39** & \begin{tabular}{|l|}
$\mathbf{7 8 . 9 4} * *$ \\
\end{tabular} & \begin{tabular}{|l|l|}
$\mathbf{7 7 . 5 3} * *$ \\
\end{tabular} & $155.25 * *$ \\
\hline S x PD & 2 & & & 8.76 & & & 0.430 & & & $17.17 * *$ & & & 1.215 \\
\hline Error (a) & 8 & & & \begin{tabular}{|l|}
6.409 \\
\end{tabular} & & & 0.659 & & & 0.46 & & & 1.00 \\
\hline $\mathbf{G}$ & 3 & $1859.78 * *$ & 4803 ** & $6319.1^{* *}$ & $25.8 * *$ & $22.30 * *$ & $48.05 * *$ & $25.95 * *$ & $21.37 * *$ & $46.53 * *$ & $17.30 * *$ & $26.10 * *$ & 41.84** \\
\hline PD x G & 6 & 6.11** & 23.25* & $25.76 * *$ & 1.55 & 2.30* & 3.63** & 1.51 & 2.23 & 3.13* & $1.96 *$ & 1.26 & 2.63 \\
\hline SxG & 3 & & & 343.72** & & & 0.125 & & & 0.79 & & & 1.57 \\
\hline$S \times P D \times G$ & 6 & & & 3.6 & & & 0.21 & & & 0.61 & & & 0.61 \\
\hline Error(b) & 36 & & & 3.97 & & & 0.78 & & & 1.01 & & & 1.47 \\
\hline SOV & & \multicolumn{3}{|c|}{ BW (gm) } & \multicolumn{3}{|c|}{$\mathrm{L \%}$} & \multicolumn{3}{|c|}{$\mathrm{SC} / \mathrm{P}(\mathrm{gm})$} & \multicolumn{3}{|c|}{$\mathrm{SC}(\mathbf{k} / \mathbf{f}))$} \\
\hline $\mathbf{S}$ & 1 & & & $1.20 * *$ & & & $88.22 * *$ & & & $74.42 *$ & & & 0.41 \\
\hline $\mathbf{R}(\mathbf{S})$ & 4 & & & 0.02 & & & 0.405 & & & 6.19 & & & 0.71 \\
\hline PD & 2 & $0.63 * *$ & $0.75 * *$ & 1.38 *** & $18.81 * *$ & \begin{tabular}{|l|}
0.76 \\
\end{tabular} & $8.03 * *$ & $78.93 * *$ & $827.6^{* * *}$ & $1553 * *$ & $62.48 * *$ & $46.11 * *$ & 107.77 ** \\
\hline S x PD & 2 & & & 0.003 & & & $11.54 * *$ & & & 4.76 & & & 0.82 \\
\hline Error (a) & 8 & & & & & & & & & 8.900 & & & 0.66 \\
\hline G & 3 & $0.44 * *$ & 0.58** & $1.01 * *$ & $9.59 * *$ & $6.05 * *$ & $13.32 * *$ & $17.3 * *$ & $19.18 * *$ & $561.47 * *$ & $15.47 * *$ & 27.43 ** & $41.69^{* *}$ \\
\hline PD x G & 6 & 0.01 & 0.02 & 0.014 & 0.12 & 1.82 & 0.81 & $1.96 * *$ & 21.4 & 24.3 & $1.30 *$ & 2.15 & $2.81 * *$ \\
\hline $\mathbf{S} \times \mathbf{G}$ & 3 & & & 0.02 & & & 2.33* & & & 21.07 & & & 1.21 \\
\hline$S \times P D \times G$ & 6 & & & $0.001 * *$ & & & 1.13 & & & 7.4 & & & \begin{tabular}{|l|}
0.63 \\
\end{tabular} \\
\hline Error "b" & 36 & & & 0.04 & & & 0.655 & & & 11.4 & & & 0.72 \\
\hline
\end{tabular}

*and** indicated significant probability levels of 0.5 and 0.01 , respectively. PH; plant height (cm), DFF; days to first flower, DFB; days to first boll, NB/P; number of bolls per plant, BW; boll weight per gram, L\%; lint percent, SC/P(gm); seed cotton per plant in gm, SC(k/f); seed cotton per feddan in kentar,

Table (4): Effect of planting dates and genotypes on yield and yield attributed variables during the two growing seasons; 2012 and 2013.

\begin{tabular}{|c|c|c|c|c|c|c|c|c|}
\hline \multirow{2}{*}{ Main effects } & \multicolumn{2}{|c|}{ PH(cm) } & \multicolumn{2}{|c|}{ DFF } & \multicolumn{2}{|c|}{ DFB } & \multicolumn{2}{|c|}{$\mathbf{N B} / \mathbf{P}$} \\
\hline & \multirow[t]{2}{*}{2012} & \multirow[t]{2}{*}{2013} & \multirow[t]{2}{*}{2012} & \multirow[t]{2}{*}{2013} & \multirow[t]{2}{*}{2012} & \multirow[t]{2}{*}{2013} & \multirow[t]{2}{*}{2012} & \multirow[t]{2}{*}{2013} \\
\hline Planting dates & & & & & & & & \\
\hline April 15 & 133.50 & 120.00 & 75.75 & 74.83 & 126.67 & 124.92 & 17.69 & $\mathbf{1 7 . 0 8}$ \\
\hline April 30 & 139.00 & 126.75 & 72.33 & 71.33 & 122.00 & 121.42 & 15.90 & 14.50 \\
\hline May 15 & 145.83 & 134.75 & 69.67 & 69.17 & 117.92 & 119.50 & 12.63 & 12.00 \\
\hline LSD(0.05) & 1.83 & 3.62 & 0.73 & 1.08 & 0.55 & 0.94 & 0.59 & 1.49 \\
\hline \multicolumn{9}{|l|}{\begin{tabular}{|l|} 
Genotypes \\
\end{tabular}} \\
\hline Giza 86 & 148.33 & 140.67 & 75.11 & 74.11 & 124.56 & 124.22 & 15.88 & 15.00 \\
\hline $10229 \times G 86$ & 144.67 & 135.67 & 72.00 & 71.33 & 122.22 & 121.56 & 17.00 & 16.11 \\
\hline Giza 88 & 118.00 & 92.67 & 71.67 & 70.78 & 121.33 & 121.00 & 13.71 & 12.11 \\
\hline$[\mathrm{G84} \times(\mathrm{G} 70 \times 51 B)] \times \mathrm{P62}$ & 146.78 & 139.67 & 71.56 & 70.89 & 120.67 & 121.00 & 15.04 & 14.89 \\
\hline LSD $(0.05)$ & 1.04 & 2.59 & 0.87 & 0.88 & 1.01 & 0.98 & 0.58 & 1.60 \\
\hline \multirow{2}{*}{ Main effects } & \multicolumn{2}{|c|}{ BW (gm) } & \multicolumn{2}{|c|}{ LP \% } & \multicolumn{2}{|c|}{$\mathrm{SC} / \mathrm{P}(\mathrm{gm})$} & \multicolumn{2}{|c|}{$\mathrm{SC}(\mathbf{k} / \mathbf{f}))$} \\
\hline & \multirow[t]{2}{*}{2012} & \multirow[t]{2}{*}{2013} & \multirow[t]{2}{*}{2012} & \multirow[t]{2}{*}{2013} & \multirow[t]{2}{*}{2012} & \multirow[t]{2}{*}{2013} & \multirow[t]{2}{*}{2012} & \multirow[t]{2}{*}{2013} \\
\hline Planting dates & & & & & & & & \\
\hline April 15 & 2.76 & 3.04 & 38.28 & 39.27 & 41.76 & 44.74 & 12.44 & 12.41 \\
\hline April 30 & 2.53 & 2.78 & 37.81 & 39.75 & 35.38 & 36.60 & 10.69 & 10.6 \\
\hline May 15 & 2.3 & 2.54 & 35.92 & 39.63 & 26.23 & 28.13 & 7.92 & 8.49 \\
\hline LSD(0.05) & 0.28 & 0.17 & 0.55 & NS & 2.35 & 4.15 & 0.69 & 1.11 \\
\hline \multicolumn{9}{|l|}{ Genotypes } \\
\hline Giza 86 & 2.44 & 2.69 & 36.94 & 40.01 & 34.79 & 37.24 & 10.48 & 10.81 \\
\hline $10229 \times G 86$ & 2.82 & 3.12 & 38.58 & \begin{tabular}{|l|}
39.89 \\
\end{tabular} & 40.71 & 43.10 & 11.96 & 12.34 \\
\hline Giza 88 & 2.3 & 2.52 & 36.16 & \begin{tabular}{|l|}
38.32 \\
\end{tabular} & 28.74 & 27.80 & 8.76 & 8.13 \\
\hline$[\mathrm{G84} \times(\mathrm{G} 70 \times 51 \mathrm{~B})] \times \mathrm{P62}$ & 2.56 & 2.82 & 37.67 & 39.98 & 33.59 & 37.82 & 10.21 & 10.71 \\
\hline $\operatorname{LSD}(\mathbf{0 . 0 5})$ & 0.18 & 0.20 & 0.83 & 0.77 & 1.96 & 4.32 & 0.59 & 1.03 \\
\hline
\end{tabular}

PH; plant height (cm), DFF; days to first flower, DFB; days to first boll, NB/P; number of bolls per plant, BW; boll weight per gram, L\%; lint percent, SC/P; seed cotton per plant and SC(k/f); seed cotton per feddan. 
cultivar Giza 86 gave the tallest plants (148.33 and $140.67 \mathrm{~cm}$ ) in both seasons, respectively. These results explained that Egyptian cotton genotypes are influenced more or less by environmental conditions.

Interaction between planting dates and genotypes (Table 5) showed that the third planting date and cultivar Giza 86 resulted in the highest PH (155 and $148 \mathrm{~cm})$ in both seasons, respectively. The significant interaction between planting dates and cotton genotypes indicated that plant elongation was governed by PD x G interaction. The significant differences in $\mathrm{PH}$ among the four cotton genotypes could be attributed to the differences in their genetic background. In general, the significant increase of cotton plant height caused by late planting could be attributed to the increase of air and soil temperatures at the time of planting and during the early growth stages (Table 1). An increase in air temperature, particularly during night, where more photosynthesis, built during day time, might have been partitioned towards plant elongation. However, Boquet and Clawson (2009) reported reverse direction in that relationship especially when planting time reached cutout.

It is important to answer the question regarding whether the second 15-day delay of planting (from 30 April to 15 May ) had a similar negative effect on seed cotton yield / plant as the first 15- days ones (from 15 April to 30 April ) and how much that reduction could be. Therefore, the response equations of $\mathrm{PH}$ to delay of planting for the two seasons were depicted in Fig. (1). Regression line indicated that the relationship between PD and plant height increased linearly by 6.16 and $7.37 \mathrm{~cm}$ with each PD unit delay in 2012 and 2013, respectively. Moreover, the linear relationship

Table (5): Interaction between planting dates and genotypes for yield and yield attributes during the two growing seasons 2012 and 2013.

\begin{tabular}{|c|c|c|c|c|c|c|c|c|c|c|c|c|}
\hline \multirow{3}{*}{ Treatments } & \multicolumn{3}{|c|}{ PH $(\mathbf{c m})$} & \multicolumn{3}{|c|}{ DFF } & \multicolumn{3}{|c|}{ DFB } & \multicolumn{3}{|c|}{$\mathbf{N B} / \mathbf{P}$} \\
\hline & \multicolumn{12}{|c|}{ Planting Dates } \\
\hline & D 1 & D 2 & D 3 & D 1 & D 2 & D 3 & D 1 & D 2 & D 3 & D 1 & D 2 & D 3 \\
\hline Genotypes & \multicolumn{12}{|c|}{2012} \\
\hline Giza 86 & 143.00 & 147.00 & 155.00 & 78.33 & 75.00 & 72.00 & 128.31 & 125.00 & 120.00 & 18.00 & 16.13 & 13.50 \\
\hline $10229 \times G 86$ & 140.00 & 144.00 & 150.00 & 76.00 & 71.00 & 69.00 & 127.00 & 121.70 & 118.00 & 18.60 & 17.07 & 15.30 \\
\hline Giza 88 & 110.00 & 118.00 & 126.00 & 75.00 & 71.30 & 68.65 & 126.70 & 121.00 & 116.00 & 16.53 & 14.60 & 10.00 \\
\hline$[\mathrm{G84} \times($ G70 $\times 51 B)] \times P 62$ & 41.00 & 147.00 & 152.33 & 73.67 & 72.00 & 69.00 & 124.72 & 120.38 & 117.00 & 17.63 & 15.80 & 11.70 \\
\hline LSD (0.05) & \multicolumn{3}{|c|}{1.81} & \multicolumn{3}{|c|}{ NS } & \multicolumn{3}{|c|}{ NS } & \multicolumn{3}{|c|}{1.00} \\
\hline Genotypes & \multicolumn{12}{|c|}{2013} \\
\hline Giza 86 & 135.00 & 139.00 & 148.00 & 77.33 & 74.00 & 71.00 & 127.28 & 124.00 & 121.00 & 17.80 & 14.30 & 13.30 \\
\hline $10229 \times G 86$ & 131.00 & 135.00 & 141.00 & 75.00 & 70.00 & 69.00 & 125.00 & 120.00 & 119.00 & 18.67 & 15.67 & 14.00 \\
\hline Giza 88 & 81.00 & 94.00 & 103.00 & 74.34 & 70.00 & 68.00 & 124.67 & 120.28 & 118.00 & 14.30 & 13.00 & 9.00 \\
\hline$[\mathrm{G84} \times(\mathrm{G70} \times 51 \mathrm{~B})] \times \mathrm{P62}$ & 133.00 & 139.00 & 147.00 & 73.72 & 71.00 & 69.00 & 124.69 & 121.00 & 119.00 & 14.70 & 15.00 & 12.00 \\
\hline LSD(C & \multirow{2}{*}{\multicolumn{3}{|c|}{$\begin{array}{c}4.48 \\
\text { BW(gm) }\end{array}$}} & \multirow{2}{*}{\multicolumn{3}{|c|}{$\begin{array}{c}1.53 \\
\mathrm{P} \%\end{array}$}} & \multicolumn{3}{|c|}{ NS } & \multicolumn{3}{|c|}{ NS } \\
\hline \multirow{3}{*}{ Treatments } & & & & & & & & $\mathbf{C} / \mathbf{P}(\mathrm{gm}$ & & & $\mathrm{SC}(\mathrm{k} / \mathrm{f})$ & \\
\hline & \multicolumn{12}{|c|}{ Planting Dates } \\
\hline & D 1 & D 2 & D 3 & D 1 & D 2 & D 3 & D 1 & D 2 & D 3 & D 1 & D 2 & D 3 \\
\hline Genoty & \multicolumn{12}{|c|}{2012} \\
\hline Giza 86 & 2.73 & 2.40 & 2.20 & 38.00 & 37.50 & 35.33 & 42.90 & 34.80 & 26.67 & 12.73 & 10.6 & 8.10 \\
\hline $10229 \times G 86$ & 3.00 & 2.87 & 2.60 & 39.57 & 38.77 & 37.40 & 45.87 & 41.03 & 35.23 & 13.23 & 12.13 & 10.50 \\
\hline Giza 88 & 2.50 & 2.30 & 2.10 & 37.07 & 36.67 & 34.73 & 37.13 & 30.23 & 18.87 & 11.30 & 9.23 & 5.73 \\
\hline$[\mathrm{G84} \times(\mathrm{G} 70 \times 51 B)] \times \mathrm{P62}$ & 2.80 & 2.57 & 2.30 & 38.5 & 38.3 & 36.20 & 41.13 & 35.47 & 24.17 & 12.50 & 10.8 & 7.33 \\
\hline LSD $(0.05)$ & \multicolumn{3}{|c|}{ NS } & \multicolumn{3}{|c|}{ NS } & \multicolumn{3}{|c|}{ NS } & \multicolumn{3}{|c|}{1.02} \\
\hline Genotypes & \multicolumn{12}{|c|}{2013} \\
\hline Giza 86 & $\mathbf{3 . 0 3}$ & 2.60 & 2.40 & 39.37 & 40.47 & 40.20 & 47.40 & 33.53 & 30.80 & 12.83 & 9.80 & 9.80 \\
\hline $10229 \times G 86$ & 3.30 & 3.20 & 2.90 & 40.30 & 40.03 & 39.33 & 48.87 & 44.73 & 35.70 & 13.60 & 12.73 & 10.70 \\
\hline Giza 88 & 2.73 & 2.50 & 2.30 & 37.23 & 39.27 & 38.47 & 35.10 & 29.70 & 18.60 & 10.27 & 8.67 & 5.47 \\
\hline$[\mathrm{G84} \times(\mathrm{G} 70 \times 51 B)] \times \mathrm{P62}$ & 3.10 & 2.80 & 2.50 & 40.17 & 39.23 & \begin{tabular}{|l|}
36.20 \\
\end{tabular} & 47.60 & 28.43 & 27.43 & 12.83 & 11.20 & 8.00 \\
\hline LSD (0.05) & \multicolumn{3}{|c|}{ NS } & \multicolumn{3}{|c|}{ NS } & \multicolumn{3}{|c|}{ NS } & \multicolumn{3}{|c|}{ NS } \\
\hline
\end{tabular}

PH; plant height (cm), DFF; days to first flower, DFB; days to first boll, NB/P; number of bolls per plant, BW; boll weight per gram, L\%; lint percent, SC/P; seed cotton per plant and SC (k/f); seed cotton per feddan 
was very informative since the degree to which the data clustered around the straight line was $99 \%$ in both seasons. However, Boquet and Clawson (2009) reported reverse direction in that relationship especially when time plants reached cutout.

\subsubsection{Days to first flower and to first boll}

The effects of planting dates and genotypes on DFF were significant in both seasons (Table 4). Sowing on May 15 gave the lowest averages (69.67 and 69.17 day) in both seasons, respectively. The cultivar Giza 88 (the shortest in both season) and the cross \{G84 $\times$ $(\mathrm{G} 70 \times 51 \mathrm{~B})\} \times$ P62 gave the earliest reading of days to first flower in the first (71.67 and 71.56 day) and second (70.78 and 70.89 day) seasons, respectively. Effect of $P D \times G$ interaction revealed that the shortest duration to first flower was recorded by cultivar Giza 88 at D3 (Table 5 ). This interaction was significant only in the second season. Effect of planting dates and genotypes on DFB was significant in both seasons (Table 4). Sowing on May 15 gave the shortest period to first boll (117.92 and 119.50 day) in both seasons, respectively. Giza 88 gave the earliest DFB (120.67 and 121.00 day) in both seasons, respectively. The interaction between sowing dates and genotypes was not significant in both seasons (Table 5).

Response equations (Fig. 1) shows that the unity decline in DFF associated with each unity delay in PD was 3.04 and 2.8 day in the first and second seasons, respectively. Days to first boll decline were 4.3 and 2.7 day in the first and second, respectively. Thus, current results indicated a photoperiodic thermo-periodic interaction effect on the duration to first flower. With each 15-day delay in planting, the number of long days was decreased where plants were able to perform more vegetative rather than reproductive growth. Previous studies revealed that cotton earliness based-growth traits (DFF and DFB) were influenced by the prevailing weather conditions and cultural practices (Pettigrew and Meredith, 2009).

The number of open bolls /plant (NB/P) and boll weight (BW): Mean performance and interaction of $\mathrm{NB} / \mathrm{P}$ and $\mathrm{BW}$ are presented in Tables (4 and 5). Planting date had significant effect on NB/P and BW in both seasons. The highest average of NB/P was obtained from sowing on April 15 in both seasons indicating that early sowing significantly increased NB/P. Genotype $10229 \times G 86$ gave the highest NB/P in both seasons (17.00 and 16.11 bolls/plant). The interaction between sowing dates and genotypes had a significant effect in the first season only. Genotype $10229 \times$ G86 and sowing on April 15 gave the NB/P (18.60 bolls). Planting on April 15 resulted in the heaviest means of boll weight (2.76 and $3.04 \mathrm{gm}$ ) in both seasons, respectively. Genotype 10299×G86 produced the heaviest means of boll weight (2.82 and $3.12 \mathrm{gm}$ ) in the two seasons, respectively. In contrast, Giza 88 gave the lightest boll weight (2.30 and $2.52 \mathrm{gm}$ ) in both seasons, respectively. Boll weight interactions were not significant in both seasons (Table 5). This implied that the current genotypes, especially the promising cross 10229 , could tolerate the stress of late and severe late sowing with respect to these two yield determinant traits. The response equations showed that the trend of significant reduction in performance of NB/P and BW (gm) associated with each delay in PD still effective (Fig. 1). Linear regression showed that a unit delay in PD resulted into a proportional decrease of 0.25 and 0.22 boll/plant in S1 and S2, respectively.

\subsubsection{Lint percentage (LP), Seed cotton per plant (SC/P) and per feddan (SC k/f)}

Data presented in Tables (4 and 5) revealed that planting dates varied significantly in lint percentage in the first season. Earliest planting date (April 15) produced the highest significant performance lint percentage (38.28\%) at the first season, moreover, delayed sowing date decreased lint $\%$ at the same season. Genotypes significantly affected lint \%. Genotypes $10229 \times$ G86 gave the highest average in the first season $(38.58 \%)$ and Giza 86 gave the highest average $(40.01 \%)$ in the second season. The interaction between planting dates and genotypes had no significant effect on lint $\%$ in both seasons. Tables (4 and 5) indicated that planting date and genotypes had significant effects on seed cotton yield per plant in grams and per feddan in kentar in both seasons. The highest $\mathrm{SC} / \mathrm{P}$ was obtained from the earliest planting date on April 15 (41.76 and 44.76 gm) in both seasons, respectively. This may be attributed to 
the increased number of bolls per plant and boll weight in the early sowing date. The same trend was shown in seed cotton per feddan, since the highest average (12.44 and $12.41 \mathrm{ken} / \mathrm{fed}$ ) was recorded on April 15 plantings for the first and second season, respectively. Genotype $10229 \times$ G86 gave the highest averages of seed cotton yield per plant (40.71and $43.10 \mathrm{gm}$ ) and per feddan (11.90 and $12.34 \mathrm{k} / \mathrm{f})$ in both seasons, respectively. The two promising crosses were significantly better than their corresponding cultivars especially in yield and its attributes. Pettigrew and Meredith (2009) reported that early sowing allowed longer growing season and gave enough time to develop a heavy boll load and seed cotton yield. The planting date $x$ genotype interaction did not significantly affect the seed cotton yield per plant in both seasons indicating that the main effects of the two factors under study acted independently.

The response of the four cotton genotypes to delay of planting was almost the same when their seed cotton yield/ plant were consistently decreased with each 15- day delay in planting. To check whether the second 15-day delay of planting (from 30 April to 15 May) had a similar negative effect on seed cotton yield / plant as the first 15- days (from 15 April to 30 April),Fig. (1) depicted the response equations of the first season $\left(\hat{Y}{ }_{1}{ }^{\text {st }}\right.$ season $\left.=53.1-8.3 \times\right)$ and the second season $\left(\hat{Y}_{2}{ }^{\text {nd }}\right.$ season $\left.=49.98-7.76 \times\right)$. These equations clearly showed the linearly negative effect of delaying planting on $\mathrm{SC} / \mathrm{p}$ in the two seasons. The rate of reduction against each unit delay in planting date was 8.3 and 7.6 gm for first and second seasons, respectively. These findings clearly interpreted the results explained in Table (4), since the delayed planting from 30 April to 15 May had more adverse effect on SC/p than the delayed planting from 15 to 30 April. In other words, 6.38 and $9.15 \mathrm{gm}$ were lost in $\mathrm{SC} / \mathrm{p}$ in the first season compared with 8.14 and $8.47 \mathrm{gm}$ in the second one due to the first and second 15-day delay of planting, respectively. Data of night temperature in the two seasons (Table 1) indicated $7^{0} \mathrm{c}$ increase from June to August (the most active reproduction) in the first season compared to only $2^{0} \mathrm{c}$ increase in the second season. This could account for more adverse effect of delaying planting in the first than in the second season particularly the second delay of planting. Discussion on yield and its attributes pointed out that the current lines of the two promising crosses possessed potential to tolerate conditions of late planting. Thus, these genotypes can be adopted to take part in the breeding programs aimed at developing barbadense genotypes that can be grown under late planting conditions.

\subsection{Fiber properties}

Based on the fiber properties performance for the two studied factors and their interaction, the mean performance of fiber length (UHML mm) for the three PDs and the four genotypes in both seasons are presented in Tables (6 and 7). Effects of the planting dates and genotypes were significant in both seasons but their interaction was not significant. The first date (April 15) produced the highest UHML (34.31 and 34.40 $\mathrm{mm}$ ) in both seasons, respectively. The least values (32.73 and $32.34 \mathrm{~mm}$ ) were obtained from the latest planting date (May 15).Cultivar Giza 88 belonging to extra long staple cottons, surpassed all other genotypes by recording fiber length of 33.83 and $34.34 \mathrm{~mm}$ in S1 and S2, respectively. The superiority of date one in fiber traits may be due to that the early planting afforded cotton plants more vegetative growth, resulting in greater accumulation of dry matter, which enhanced cotton fiber length. Fiber length was decreased by 0.7 and $1.02 \mathrm{~mm}$, respectively, in S1 and S2 against each unit delay in PD(Fig. 2).

Fiber strength (g/tex) was significant for the two factors under study, while the PD x G interaction was not significant in both seasons (Tables 6 and 7). The first planting date (April 15) gave the strongest fibers (46.53 and 46.00 $\mathrm{g} / \mathrm{tex})$ in both seasons. Genotype $10299 \times \mathrm{G} 86$ recorded the highest fiber strength (47.34 g/tex) in the first season, but Giza 88 was the strongest in the second season $(44.19 \mathrm{~g} / \mathrm{tex})$.

Fig. (2) shows that the significant decline in FL associated with each delay in planting date were $0.78 \mathrm{~mm}$ and $1.02 \mathrm{~mm}$ in both seasons, respectively. Polynomial of the second degree controlled the regression of fiber strength on planting date in both seasons with significant decline of 1.2 and $0.8 \mathrm{~g} / \mathrm{tex}$ in season one and two, respectively.These results are in conformity 

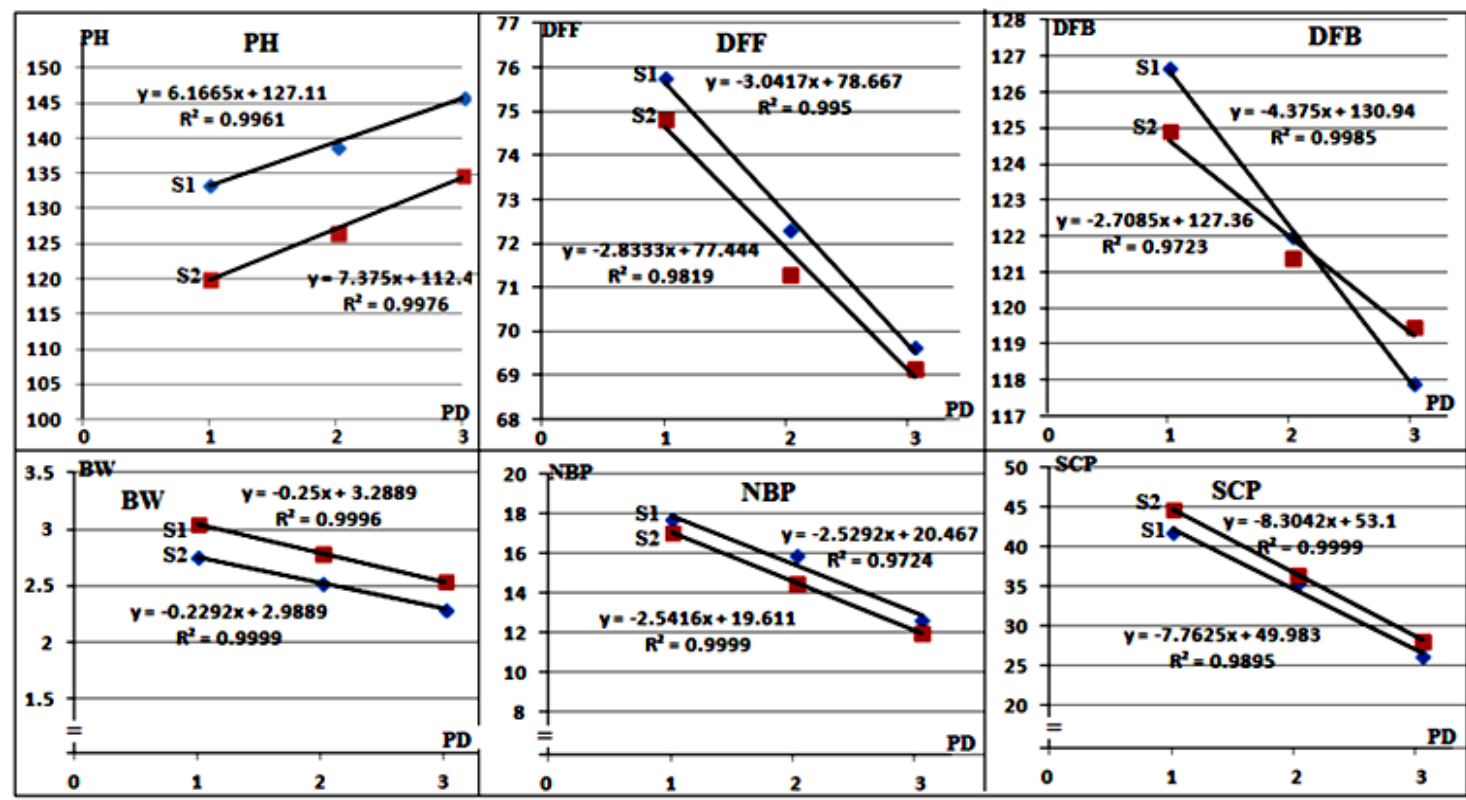

(o first flower, to first boll, boll weight, number of bolls per plant and seed cotton per plant to the three planting dates for the two growing seasons; 2012 (S1) and 2013 (S2).
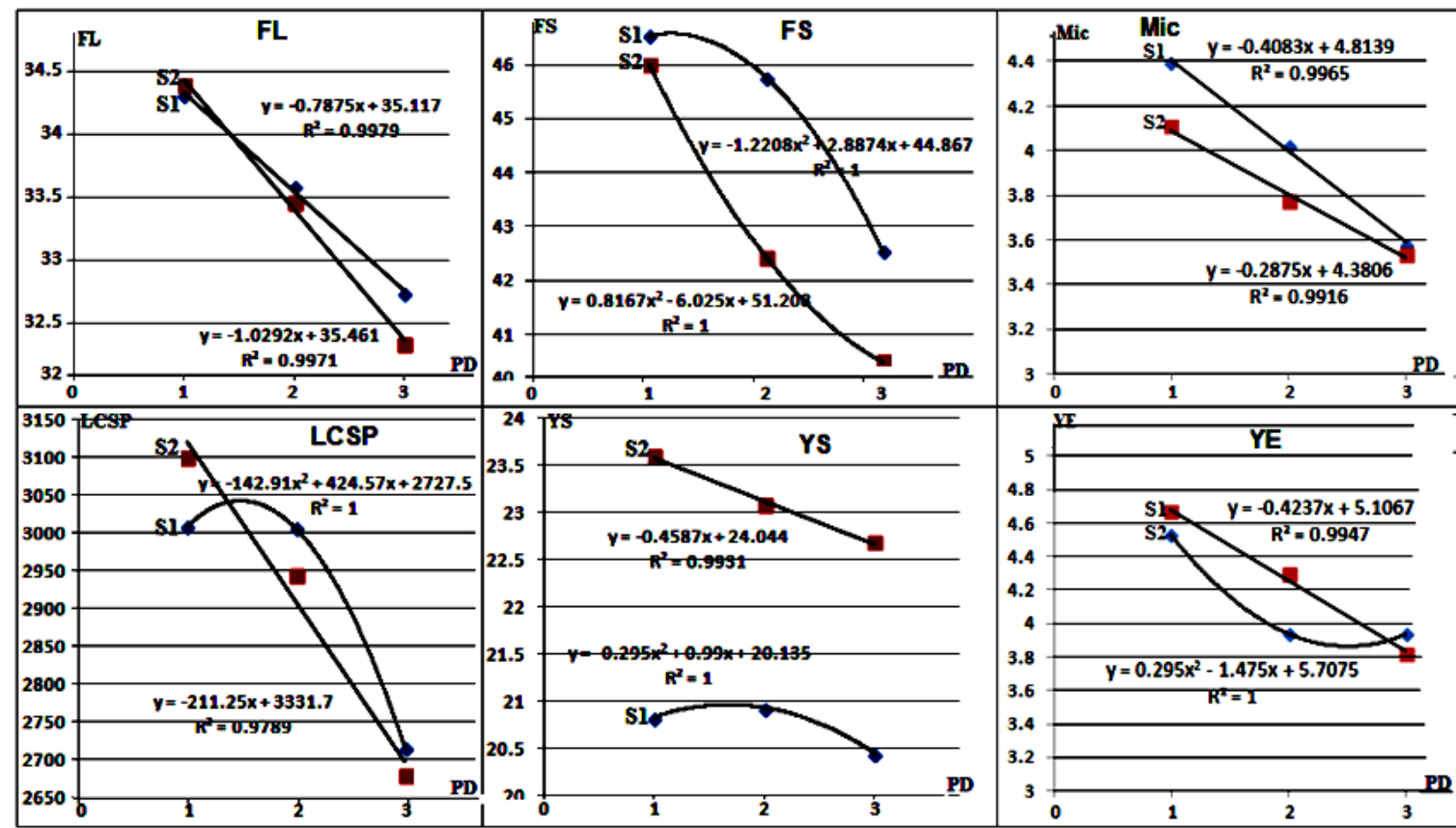

Fig.(2) : Response curves of fiber length, strength, micromaire value, lea connt, yan strength and yearn elongation to the three planting dates for the two growing seasons; 2012 (S1) and 2013 (S2)

with those of Constable et al. (1976). However, Bridge et al. (1971) reported that PDs had no effect on fiber strength. Bauer et al. (1998) and Sekhon and Singh (2013) reported the relationship between planting date, potassium nutrition and fiber properties. Zhao et al. (2012) reported that the decline in cotton yield and fiber quality (strength) associated with late planting were due to the decline in cellulose content and sucrose transformation. Tables (6 and 7) indicated that planting dates and genotypes had significant effects on micronaire values that tended to decrease as sowing date was delayed in both seasons. Planting on May 15 gave the best reading (3.58 and 3.53) in both 
seasons, respectively. Cultivar Giza 88 was the finest one (3.77 and 3.46) followed by genotype [G84 $\times(\mathrm{G} 70 \times 51 \mathrm{~B}) \times \mathrm{P} 62](4.10$ and 3.74) in both seasons, respectively. The interaction between planting dates and genotypes had no significant effect on micronaire value. In fact, micronaire value has no unit and is a staple quality trait that expresses a combination of fiber fineness and fiber maturity. The micronaire $>4.5$ may indicate that the fiber is coarse as it results in too few fibers in yarn cross section, reducing its strength. This defiantly is undesirable for spinners. The micronaire value $<3.8$ may mean that fibers are immature, leading to breakages in fibers within the yarn. The optimal range is from 3.8 to 4.5
(Bange et al., 2008). The linear response of micronaire reading against delayed PD presented in Fig. (2) shows a decreased performance in micronaire value by 0.4 and 0.02 units with each unit delay in PDs for S1 and S2, respectively. Similar findings were reported by Culp and Harrell (1972). However, Bilbro and Ray (1973) and Wrather et al. (2008) pointed out that fiber fineness improved in late sowing.

Data presented in Tables (6 and 7) clarified that uniformity index values for the two factors under study were significant in both seasons. The first planting date (April 15) gave the highest uniformity index (88.06 and $87.38 \%$ ) for the two seasons, respectively. Genotype (10299

Table (6): Effect of planting dates and genotypes on fiber properties during the two growing seasons (2012 and 2013)

\begin{tabular}{|c|c|c|c|c|c|c|c|c|c|c|}
\hline Main effects & \multicolumn{2}{|c|}{ FL(mm) } & \multicolumn{2}{|c|}{ FS(g/tex ) } & \multicolumn{2}{|c|}{ Mic } & \multicolumn{2}{|c|}{ FU (\%) } & \multicolumn{2}{|c|}{$\operatorname{FE}(\%)$} \\
\hline Planting dates & 2012 & 2013 & 2012 & 2013 & 2012 & 2013 & 2012 & 2013 & 2012 & 2013 \\
\hline April 15 & 34.31 & 34.40 & 46.53 & 46.00 & 4.39 & 4.11 & 88.06 & 87.38 & 7.21 & 6.99 \\
\hline April 30 & 33.59 & 33.47 & 45.76 & 42.51 & 4.03 & 3.78 & 86.8 & 85.53 & 6.85 & 6.48 \\
\hline May 15 & 32.73 & 32.34 & 42.54 & 40.48 & 3.58 & 3.53 & 85.3 & 84.28 & 6.48 & 5.92 \\
\hline LSD $(0.05)$ & 0.93 & 0.75 & 1.64 & 0.85 & 0.13 & 0.25 & 0.58 & 0.71 & 0.60 & 0.20 \\
\hline Genotypes & & & & & & & & & & \\
\hline Giza 86 & 33.5 & 32.23 & 42.26 & 41.51 & 4.00 & 4.18 & 86.79 & 85.26 & 7.43 & 6.71 \\
\hline $10229 \times G 86$ & 33.53 & 32.93 & 47.34 & 42.9 & 4.12 & 3.84 & 87.07 & 84.91 & 7.28 & 6.57 \\
\hline Giza 88 & 33.83 & 34.34 & 44.26 & 44.19 & 3.77 & 3.46 & 86.87 & 85.94 & 6.44 & 6.00 \\
\hline$[\mathrm{G84} \times(\mathrm{G70} \times 51 \mathrm{~B})] \times \mathrm{P62}$ & 33.31 & 34.10 & 45.92 & 43.39 & 4.10 & 3.74 & 86.14 & 86.82 & 6.22 & 6.57 \\
\hline LSD(0.05) & 0.49 & 0.59 & 1.18 & 0.99 & 0.26 & 0.3 & 0.94 & 0.67 & 0.10 & 0.18 \\
\hline
\end{tabular}

FL; fiber length, FS; fiber strength, Mic; micronaire value, FU; fiber uniformity, and FE; fiber elongation

Table (7): Interaction between planting date and genotypes for fiber properties during the two growing seasons (2012 and 2013)

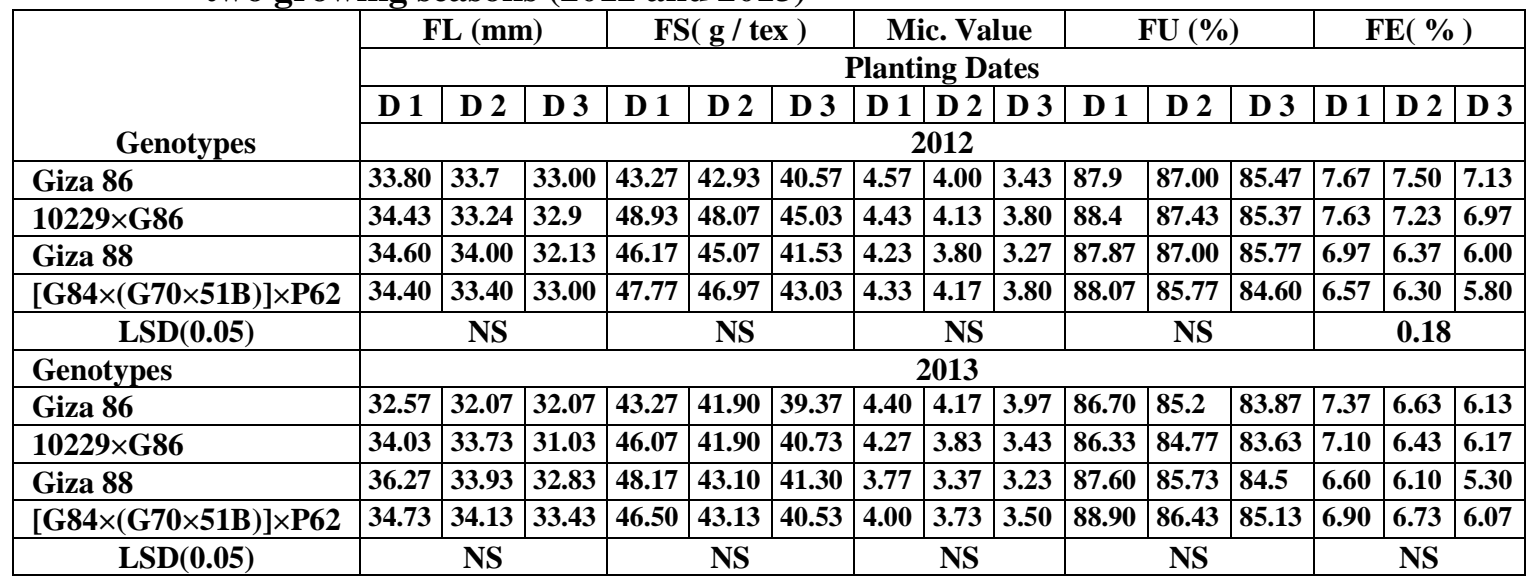

FL; fiber length, FS; fiber strength, Mic; micronaire value, FU; fiber uniformity, and FE; fiber elongation 
$\times$ G886) surpassed the other three genotypes in uniformity index value $(87.07 \%)$ in the first season. Such superiority of $86.82 \%$ was recorded by $[\mathrm{G} 84 \times(\mathrm{G} 70 \times 51 \mathrm{~B}) \times \mathrm{P} 62]$ in the second season. The highest fiber elongations of 7.21 and $6.99 \%$ were obtained from April 15 PD in both seasons, respectively. As planting date was delayed the elongation percent values were decreased. This may be attributed to an increase in fiber convolution number in early sowing dates. Cultivar Giza 86 gave the highest value of fiber elongation percent (7.43 and 6.71\%) in both seasons, respectively. The interaction between planting date and genotypes did not cause significant variation in fiber elongation percentage in both seasons. These results are in harmony with those reported by Zhao et al. (2012). However, Emara (2012) indicated that the fiber length, strength, micronaire, and uniformity were not significantly affected by sowing date.

\subsection{Yarn properties}

Planting dates and genotypes had significant effects on lea count strength product (LCSP) in both seasons (Table 8), their interaction; however, was not significant (Table 9).

Planting on April 15 gave the highest values (3092.50 and 3106.25) in the two seasons, respectively. Genotype $(10299 \times 86)$ surpassed the others (3193.33 and 3108.33) in both seasons, respectively. Planting date of single yarn strength (YS) was significant in the first season. The first planting date gave the highest single yarn strength $(23.60 \mathrm{cN} /$ tex $)$ in the second season. Genotypes were significant in both seasons (Table 8). Genotype [G84x $(\mathrm{G} 70 \times 51 \mathrm{~B})] \times \mathrm{P} 62(22.27 \mathrm{cN} / \mathrm{tex})$ surpassed the other genotypes in the first season. Such superiorly of $28.21 \mathrm{cN} /$ tex was obtained by the Cultivar Giza 88 in the second season. Yarn elongation for the two factors under study was significant in both seasons (Table 8). The first

Table (8): Effect of planting date and genotype on yearn properties during the two growing seasons.

\begin{tabular}{|c|c|c|c|c|c|c|c|c|}
\hline \multirow{2}{*}{ Main effects } & \multicolumn{2}{|c|}{ LCSP } & \multicolumn{2}{|c|}{ YS (cN/tex) } & \multicolumn{2}{|c|}{ YE (\%) } & \multicolumn{2}{|c|}{ Even $(\mathrm{CV})$} \\
\hline & 2012 & 2013 & 2012 & 2013 & 2012 & 2013 & 2012 & 2013 \\
\hline \multicolumn{9}{|l|}{ Planting dates } \\
\hline Apr 15 & 3092.5 & 3106.25 & 20.83 & 23.61 & 4.53 & 4.65 & 19.40 & 20.78 \\
\hline Apr 30 & 3005 & 2945 & 20.94 & 23.33 & 3.94 & 4.3 & 19.56 & 20.81 \\
\hline May 15 & 2715 & 2680 & 20.45 & 22.74 & 3.94 & 3.82 & 19.81 & 20.86 \\
\hline LSD(0.05) & 268.08 & $\mathbf{1 5 1 . 8 3}$ & 0.28 & NS & 0.23 & $\mathbf{0 . 3 1}$ & NS & NS \\
\hline \multicolumn{9}{|l|}{ Genotypes } \\
\hline Giza 86 & 2736.67 & 2725 & 16.65 & 18.27 & 3.56 & 3.39 & 16.44 & 20.50 \\
\hline $10229 \times G 86$ & 3193.33 & 3108.33 & 21.86 & 20.32 & 4.02 & 5.25 & 21.86 & 21.40 \\
\hline Giza 88 & 2853.33 & 2805 & 22.18 & 28.21 & 4.8 & 3.92 & 20.58 & 21.66 \\
\hline$[$ G84 $\times(G 70 \times 51 B)] \times P 62$ & 2966.67 & 3003 & 22.27 & 26.1 & 4.15 & 4.45 & 19.49 & 19.70 \\
\hline $\operatorname{LSD}(0.05)$ & 186.81 & 104.53 & 0.29 & 0.51 & 0.15 & 0.52 & 0.29 & 0.61 \\
\hline
\end{tabular}

LCSP; lea count strength product, YS; single yarn strength, YE; yarn elongation, and Even (CV); yarn evenness (CV)

Table (9): Interaction between planting date and genotype for yarn properties during the two growing seasons

\begin{tabular}{|c|c|c|c|c|c|c|c|c|c|c|c|c|}
\hline \multirow[b]{3}{*}{ Treatments } & \multicolumn{3}{|c|}{ LCSP } & \multicolumn{3}{|c|}{ YS (cN/tex) } & \multicolumn{3}{|c|}{ YE (\%) } & \multicolumn{3}{|c|}{ Even (CV) } \\
\hline & \multicolumn{12}{|c|}{ Planting date } \\
\hline & D 1 & D 2 & D 3 & D 1 & D 2 & D 3 & D 1 & D 2 & D 3 & D 1 & D 2 & D 3 \\
\hline Genotypes & \multicolumn{12}{|c|}{2012} \\
\hline \begin{tabular}{|l|} 
Giza 86 \\
\end{tabular} & 2900 & 2820 & 2490 & \begin{tabular}{|l|}
16.8 \\
\end{tabular} & 16.74 & \begin{tabular}{|l|l|}
16.4 \\
\end{tabular} & 4.25 & 3.31 & 3.12 & 16.29 & 16.25 & 16.68 \\
\hline $10229 \times G 86$ & 3300 & 3350 & 2930 & 21.73 & 22.46 & 21.39 & 4.01 & 4.02 & 4.03 & 21.68 & 21.89 & 22.02 \\
\hline Giza 88 & 3070 & 2850 & 2640 & 22.36 & 22.24 & 21.93 & 5.51 & 4.39 & 4.51 & 20.34 & 20.50 & 20.92 \\
\hline$[$ G84 $\times($ G70 $\times 51 B)] \times P 62$ & 3100 & 3000 & 2800 & 22.43 & 22.3 & 22.08 & 4.34 & 4.03 & 4.09 & 19.30 & 19.53 & 19.64 \\
\hline $\operatorname{LSD}(0.05)$ & \multicolumn{3}{|c|}{ NS } & \multicolumn{3}{|c|}{ NS } & \multicolumn{3}{|c|}{0.27} & \multicolumn{3}{|c|}{ NS } \\
\hline Genotypes & \multicolumn{12}{|c|}{2013} \\
\hline Giza 86 & 2840 & 2780 & 2555 & 18.67 & 18.15 & 18 & 3.92 & 3.14 & 3.12 & 20.60 & 20.13 & 20.77 \\
\hline $10229 \times G 86$ & 3380 & 3155 & 2790 & 20.73 & 20.2 & 20.02 & 5.81 & 5.67 & 4.28 & 21.15 & 21.59 & 21.46 \\
\hline Giza 88 & 3005 & 2795 & 2615 & 28.59 & 28.21 & 27.83 & 3.96 & 3.92 & 3.88 & 21.73 & 21.67 & 21.60 \\
\hline$[$ G84 $\times($ G70 $\times 51 B)] \times P 62$ & 3200 & 3050 & 2760 & 26.44 & 26.77 & 25.09 & 4.91 & 4.45 & 3.99 & 19.64 & 19.85 & 19.63 \\
\hline $\operatorname{LSD}(0.05)$ & \multicolumn{3}{|c|}{ NS } & \multicolumn{3}{|c|}{ NS } & \multicolumn{3}{|c|}{ NS } & \multicolumn{3}{|c|}{ NS } \\
\hline
\end{tabular}

LCSP; lea count strength product, YS; single yarn strength, YE; yarn elongation, and Even (CV); yarn evenness (CV) 
planting date (April 15) gave the highest yarn elongation percent $(4.53$ and $4.65 \%)$ in both seasons, respectively. Genotype 10299×86 $(5.25 \%)$ surpassed the other genotypes in the second season. PD x G was not significant in the second season (Table 9). Table (8) showed that planting dates had no effect on yarn evenness in both seasons; it was slightly increased by delaying planting date. Effect of genotypes, however, was significant in both seasons with genotype $10229 \times \mathrm{G} 86(21.86 \%)$ as the highest overall in season 1 . The PD x G interaction was not significant in both seasons (Table 9).

Yarn evenness is a measure of the level of variation in yarn linear density or mass per unit length of yarn. A yarn with poor evenness (high CV \%) had high imperfections (thick, thin places and neps along yarn length, data not shown).

Yarn properties decreased with delaying planting dates. Response equations of these properties to delay of planting were calculated and are presented in Figure (2). These equations clearly indicated that the negative effect of delaying planting on yarn properties was linear in the first season and however quadratic in the second one. The study pointed out that planting dates was a strong factor in determining fiber properties especially those connected to yarn spinning properties i.e., fiber length, strength, and micronaire. This was in agreement with results of Pellow et al. (1996) and Hinchliffe et al. (2011). Moreover, Bradow and Bauer (1998) reported that temperatures modified fiber properties, and genotypes interacted with temperature to modify fiber length and micronaire.

\subsection{Relationship between cotton traits and the accumulated heat units}

Table (10) presented the accumulated heat units (AHU) at 160 day after planting of each date. Data revealed that the late sowing on May15 received the highest number of AHU (1871.8 and 2167.52) in the first and second season, respectively. Heat units accumulation affected by growing season, location and agricultural treatments was reported by Bilbro (1975) and Boquet and Clawson (2009). AHU was directed to increase plant growth traits as the PD moved forwarded. Using Egyptian genotypes, Hamed (2011) reported that increases in heat units in late sowing caused an increase in plant height and the number of nodes per plant without affecting the interned length. Supak (1986) reported that the functional relationship between temperature and plant growth is not always linear as it assumed to be. Under Egyptian conditions, the longest day is on June $21^{\text {st }}$; therefore, late sown plants on May 15 had only about three weeks of long days compared with seven weeks afforded to early sown on April 15. Moreover, cotton as facultative shortday plant (Burke and Wanjura,2010) was pushed for an early reproductive growth as long days were decreased and days became shorter beyond $21^{\text {st }}$ of June when plants were only 45 -day old. These late sown plants were pushed to commit early flowering and hence set their first flower earlier than early sown ones. High temperature during May and June might magnify the effect of photoperiod where a thermo-period $x$ photoperiod interaction effect played an enhancing role on the duration to first flower and hence the number of days was decreased.

Furthermore, the total cotton yield for each PD tended to increase in favors of early sowing. The lower amounts of heat units in early sowing encouraged the formation of more sympodial per plant (Mac-Mahon and low 1972 and Young et al.,1980) that are the main carriers of fruiting sites, which in turn lead to increase the total fruiting capacity of cotton plant. Early sowing delayed the appearance of the first flower and the first boll as compared to late sowing. It utilized the lower number of $\mathrm{HU}$ from planting to first flower and the remained $\mathrm{HU}$ consumed through fruiting stage. Thus, growing cotton as early as a local climate condition is favorable key factor controls the rank growth through growing season (Young et al. 1980). Additionally, early sowing consumed a lower value of the total accumulated $\mathrm{HU}$ for producing one open boll (heat unit efficiency use (hu/boll) as shown in Table (10). Table (10) revealed the relationship between AHU and three growth traits viz., DFF, DFB and NB/P. Data revealed an increased efficiency of using the thermal heat units in early sowing, since the increased number of boll per plant in the first planting date was associated with the lower value of heat units efficient use. Early planting 
Table (10): Effect of planting date on the total heat units (THU) and heat units' efficiency (HUE) during the two growing seasons (2012 and 2013)

\begin{tabular}{|l|l|l|l|l|l|l|l|l|l|l|}
\hline \multirow{2}{*}{ PD } & \multicolumn{4}{|c|}{2012} & \multicolumn{4}{c|}{2013} \\
\cline { 2 - 11 } & AHU & DFF & DFB & NB/P & HUE (hu/boll) & AHU & DFF & DFB & NB/P & HUE(hu/boll) \\
\hline April 15 & $\mathbf{1 7 1 1 . 2 0}$ & $\mathbf{7 5 . 7 5}$ & $\mathbf{1 2 6 . 6 7}$ & $\mathbf{1 7 . 6 9}$ & $\mathbf{9 6 . 7 3}$ & $\mathbf{1 9 7 3 . 5 7}$ & $\mathbf{7 4 . 8 3}$ & $\mathbf{1 2 4 . 9 2}$ & $\mathbf{1 7 . 0 8}$ & $\mathbf{1 1 5 . 5 5}$ \\
\hline April 30 & $\mathbf{1 8 1 7 . 6 0}$ & $\mathbf{7 2 . 3 3}$ & $\mathbf{1 2 2 . 0 0}$ & $\mathbf{1 5 . 9 0}$ & $\mathbf{1 1 4 . 3 1}$ & $\mathbf{2 0 8 7 . 8 7}$ & $\mathbf{7 1 . 3 3}$ & $\mathbf{1 2 1 . 4 2}$ & $\mathbf{1 4 . 5 0}$ & $\mathbf{1 4 3 . 9 9}$ \\
\hline May 15 & $\mathbf{1 8 7 1 . 8 0}$ & $\mathbf{6 9 . 6 7}$ & $\mathbf{1 2 1 . 9 2}$ & $\mathbf{1 2 . 6 3}$ & $\mathbf{1 4 8 . 2}$ & $\mathbf{2 1 6 7 . 5 2 3}$ & $\mathbf{6 9 . 1 7}$ & $\mathbf{1 1 9 . 5 0}$ & $\mathbf{1 2 . 0 0}$ & $\mathbf{1 8 0 . 6 2}$ \\
\hline LSD(0.05) & & $\mathbf{0 . 7 3}$ & $\mathbf{0 . 5 5}$ & $\mathbf{0 . 5 9}$ & & & $\mathbf{1 . 0 8}$ & $\mathbf{0 . 9 4}$ & 1.49 & \\
\hline
\end{tabular}

on April 15 afforded cotton plants the proper durations to the first flower and to the first open boll that played a role in building up more available nutritional synthates for setting larger number of bolls/ plant and heavier boll weight. The improved plant growth was finally reflected in gaining more seed and lint cotton yield, and consequently, longer fibers, strength, fineness and uniformity than those produced in late plantings. This favorable effect was almost the same on the four cotton genotypes under study as was expressed in insignificant planting dates $\times$ genotypes interaction on most fiber and yarn properties in both seasons. The applied implication of this interpretation under current research environments is to sow cotton in suitable soil and suitable time when soil temperature at a depth of $20 \mathrm{~cm}$ reached $15^{\circ} \mathrm{C}$ at 8 am and probably continued for ten more days, i.e., early to middle April.

\section{Conclusion}

Cotton like any other plant lacks the ability to adjust internal constant temperature (Supak, 1986), thus temperature changes in growing environments associated with altering planting date deeply influence growth and development stages and consequently the mean performance. The current study aimed at exploring the variability in cotton biological traits that is a curtail step in interpreting the normality of the population under study, especially when the treatments are expected to change the gene frequency of the investigated germplasm. The current study makes obvious that sowing Egyptian ecotypes of barbadense in late sowing of the middle April can be attained with potential performance. Of course, sowing on April 15 was the best to grow cotton in suitable climatic window. Planting on April 30, for some traits, was not bad too. April 15 planting helped obtained complete thermal units requirements that seemed to meet the condition of balance between vegetative and reproductive growth stages, and consequently brought the crop to timely pick with suitable potential. The potential of the two promising crosses G84x G70xG51BxPima62 and 10229 x Giza 86 suggesting their use in replace the cultivated cultivars and utilize in breeding program aimed at improve barbadense genotype to grow under late planting conditions.

\section{REFERENCES}

Abdalla A. M. A. (2013). Joint regression and ordination analysis techniques of GXE interaction for shortening cotton growing season. Egypt. J. Plant Breed. 17(6):99-116.

Abo El-Zahab A. A. (1994). Integrated-short season production system for Egyptian cotton. Final report. Nat. Acad. Sci. Tech. NARP Grant No.34A-6-8.

Anderson T. W. and Darling D. A. (1954). A Test of Goodness-of-Fit. J. Amer. Stat. Assoc., 49: 765-769.

Asif M., Iqbal J. and Zafar Y. (2008). Genetic analysis for fiber quality traits of cotton genotypes. Pak. J. Bot., 40 (3): 1209-1215.

ASTM D4604-05. (2005).Test Methods for Measurement of Cotton Fibers by High Volume Instruments (HVI) (Motion Control Fiber Information System).Vol.7.,01Section 7.

ASTM D1578-93R00. (2005). Standard Test Method for Breaking Strength of Yarn in Skein Form. Annual Book of ASTM Standards. Vol. 7. 02 Section 7.

Anonymous (2012). Annual Technical Progress Report. Cotton Res. Inst. Ministry Agric. Egypt.

Bange M. P. and Milroy S. P. (2004). Impact of short term exposure to cold night temperature 
on early development cotton. Aust. J. Agric. Res., 55:655-664.

Bange M. P., Caton S. J. and Milroy S. P. (2008). Managing yields of high fruit retention in transgenic cotton (Gossypium hirsutum L.) using sowing date. Aust. J. Agric. Res. 59:733-741.

Baskerville G. L. and Emin P. (1969). Rapid estimation of heat unit accumulation from maximum and minimum temperature. Ecol. 50: 514-517.

Bauer P. J., May O. L. and Camberato J. J. (1998). Planting date and potassium fertility effects on cotton yield and fiber properties. J. Prod. Agric., 11:415-420.

Bilbro T. D. (1975). Relationship of air temperature to first bloom dates of cotton. Texas Agric. Exp. Station. Misc. Public., 18: 6-8.

Bilbro T.D. and Ray L. L. (1973). Effect of planting date on the yield and fiber properties of three cotton cultivars. Agron. J., 65(4): 606-609.

Boquet D. and Clawson E. (2009). Cotton planting date: yield seedling survival and plant growth. Agron. J., 101 (5): 1123-1130.

Bowman D. T. (2001). Common Use of the CV: a statistical aberration in crop performance trials. J. Cotton. Sci., 5:137-14.

Bradow J. M. and Bauer P. (1998). How Cultivar, genotype and weather determine yarn properties. Proc. Cotton Res. Conf. Athens, Greece. pp. 1070-1073.

Bridge R. R., Meredith Jr. W. R. and Chism T. F. (1971). The influence of planting date on agronomic and fiber properties of cotton. Crop Sci., 12: 353-358.

Burke J. J. and Wanjura D. F. (2010). Cotton response to temperature extremes. In physiology of cotton. Chap.12. Springer Dordrecht Heidelberg, London, New York. ISBN 978-90-481-3194-5.

Constable G. A., Harris N.Y. and Paull R. E. (1976). The effect of planting on the yield and some fiber properties of cotton in the Namoi Valley. Aust. J. Expt. Agri. and Anim. Husb., 16: 265.

Culp T.W. and Harrell D. C. (1972). Variation in fiber and yarn properties of identical checks in yield test and nursery plots of upland cotton, Gossypium hirsutum L. Crop Sci., 12: 355-358.

D'Agostino, R. and Stephens M. (1986). Tests for the Normal Distribution. In: D'Agostino, R.B. and Stephens, M.A.(eds) Goodness-ofFit Techniques. New York: Marcel Dekker. ISBN 0-8247-7487-86

Egyptian cotton Gazette (2012). The Egyptian cotton statistics. Alex. Cotton Export Assoc. Modern Press, Alex. Egypt.

Emara M. A. A. (2012). Response of cotton growth and productivity to application of potassium and zinc under normal and late sowing dates. J. Plant prod. Mans. Univ. 3(3):509-524.

Hamed F. (2011). Air thermal units in relation to growth and development of cotton plants through different sowing dates. J. Plant Prod. Mans. Univ.,UK. 2(1):1409-1419.

Hinchliffe D., Meredith Jr. W. R., Delhom C. D. and Fang D. D. (2011). Elevated growing degree days influence transition stage timing during cotton fiber development resulting in increased fiber-bundle strength. Crop Sci., 51: 534-550.

Johnson R.M., Bradow J.M., Bauer P. J. and Sadler E. J. (2002). Variability in cotton fiber yield, fiber quality, and soil properties. Agron., J. 94: 1305-1316.

Mac-Mahon J. and Low A. L. (1972). Growing degree days as a measure of temperature effects of cotton. Cotton Gr. Rev., 49: 39-49.

Pellow J. W., Cooper H. P., Palmer, J. C. and McRae, K. E. 1996. Fineness, maturity, micronaire and dye-ability of two Acala cottons. Proc. Cotton Belt. Conf., 1691-1693. Memphis, TN. USA.

Pettigrew W. T. and Meredith, Jr. W. R. (2009). Seed quality and planting date effects on cotton lint yield and fiber quality. J. Cotton. Sci., 13:37-45.

Sekhon N. K. and Singh C. B. (2013). Plant Nutrient Status during Boll Development and Seed Cotton Yield as Affected by Foliar Application of Different Sources of Potassium. Amer. J. Plant Sci.,(4): 1409-1417

Snedecor G. N. and Cochran W. G. (1983). Statistical methods. $6^{\text {th }}$ ed. Iowa State Univ. Press, USA. 
Supak J. R. (1986). Understanding and using heat units. Internet report, TAMU publication.

http://cotton.tamu.edu/General\%20Productio $\mathrm{n} / \mathrm{arch}$.

Uster News Bulletin (1998). The Third generation of Evenness Testers. Zellweger Uster AG, Switzerland. No 35.

Wrather J.A., Phillips B. J., Stevens W. E., Phillips A. S. and Vories. E. D. (2008).

Cotton planting date and plant population effects on yield and fiber quality in the
Mississippi Delta. J. Cotton Sci., 12: 1-7.

Young E. F., Taylor R. M., Petersen H. D. (1980). Days degree units in relation to vegetative development and fruiting for three cotton cultivars. Crop Sci. 20: 320-375.

Zhao W., Wang Y., Shu H., Li J. and Zhou Z. (2012). Sowing date and boll position affected boll weight, fiber quality and fiber physiological parameters in two cotton $(G$. hirsutum L.) cultivars. Afr. J. Agric. Res., 7(45): 6073-6081.

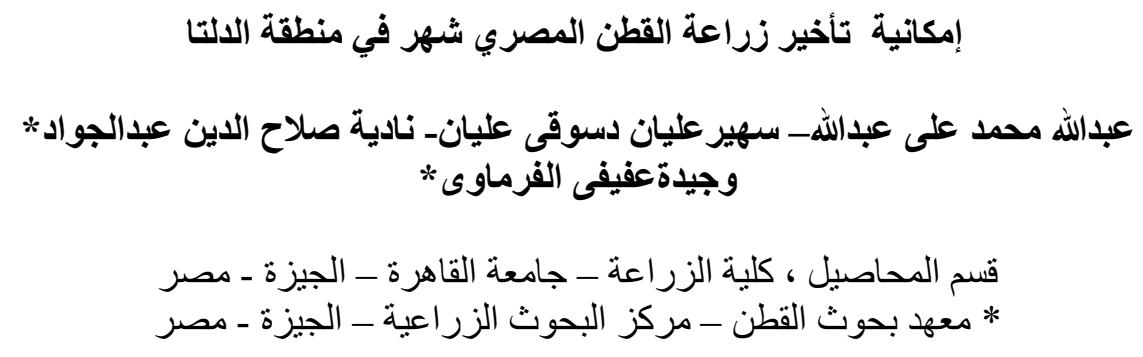

يو اجه مزارعي القطن المصري مشكلة يصعب تجنبها وهي تأخير زر اعة القطب القطن عن اخر مارس أوالأسبوع الأول

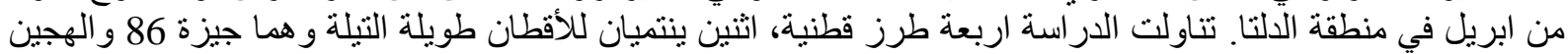

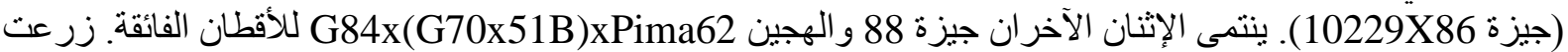

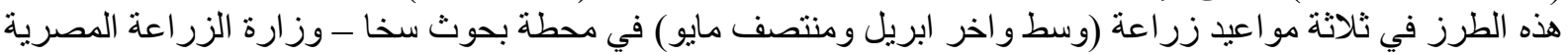

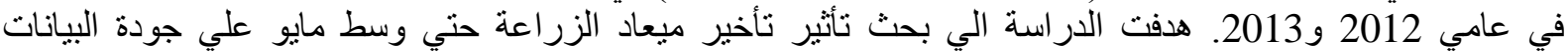

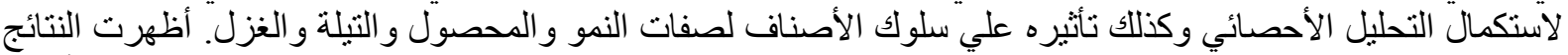

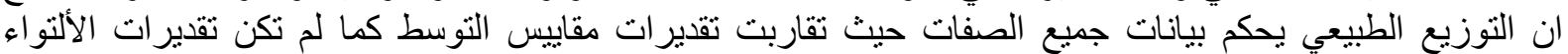

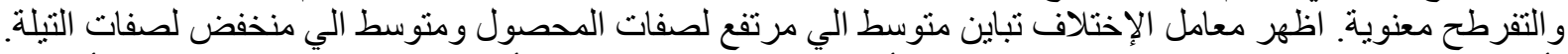

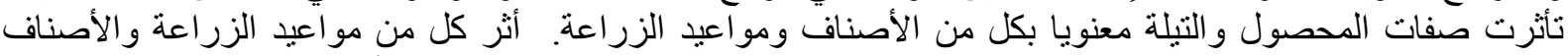

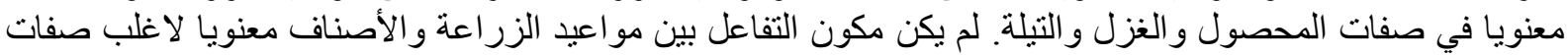

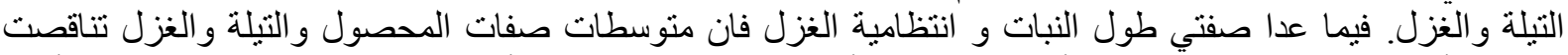

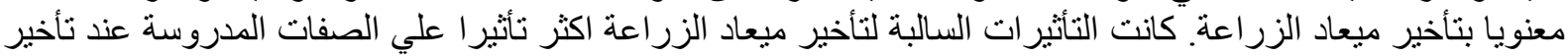

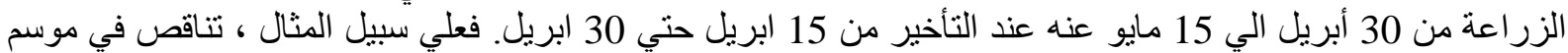

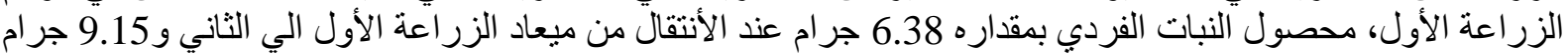

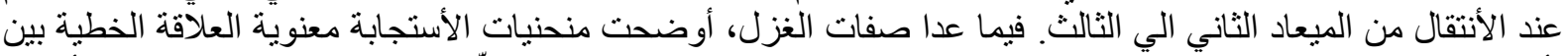

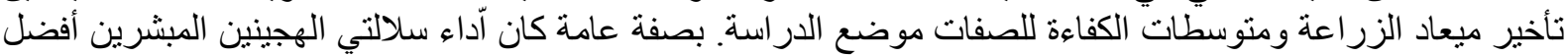

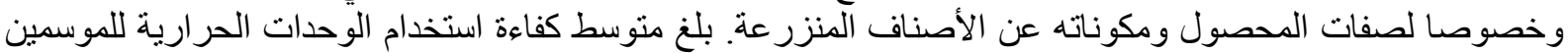
مقاسة بعدد اللوز الناضج بالنبات المقابل لكل وحدة حرارية 106.14 وحدة حرارية الإية للوزة و و

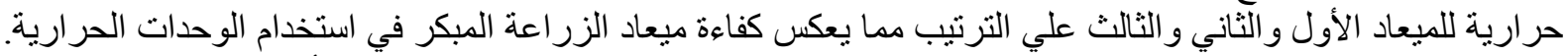

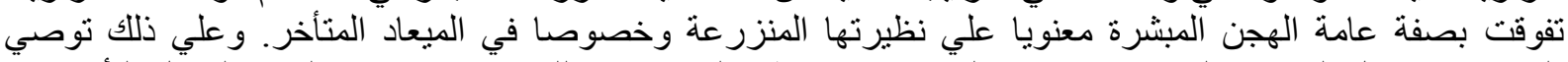

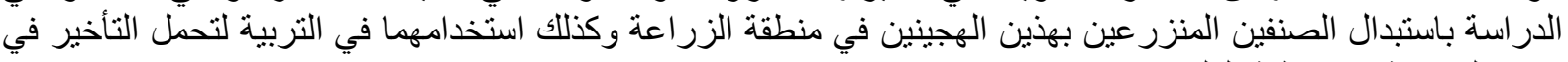
ميعاد الزر اعة في منطقة الدلتا. 